\title{
PENGOLAHAN LIMBAH CAIR RUMAH MAKAN MENGGUNAKAN SISTEM KOMBINASI ABR DAN WETLAND DENGAN SISTEM KONTINYU
}

\author{
Wiwien Mardianto ${ }^{1}$, Isna Apriani ${ }^{1}$, Rita Hayati \\ ${ }^{1}$ Program Studi Teknik Lingkungan, Fakultas Teknik, Universitas Tanjungpura, Pontianak \\ 2Program Studi Ilmu Tanah, Fakultas Pertanian, Universitas Tanjungpura, Pontianak \\ Email : We winmardianto@yahoo.co.id
}

\begin{abstract}
ABSTRAK
Salah satu masalah yang timbul akibat meningkatnya kegiatan rumah makan/restaurant adalah tercemarnya air pada sumber-sumber air karena menerima beban pencemaran yang melampaui daya dukungnya. Berdasarkan tingkat kepadatan penduduk dan laju pertumbuhan penduduk di Indonesia, maka air limbah yang berasal dari rumah makan untuk masa yang akan datang berpotensi menjadi ancaman yang cukup serius terhadap pencemaran lingkungan perairan. Penelitian ini bertujuan untuk : (1) Mengetahui karakteristik limbah cair domestik rumah makan Raje Laot; (2) Mengetahui efektifitas pengolahan limbah cair domestik dengan menggunakan kombinasi prosese Anaerobic baffle reactor (ABR) dan wetland dalam satu unit teknologi pengolahan; (3) Mengetahui waktu tinggal terbaik untuk mengolah limbah cair domestik dengan kombinasi proses Anaerobic baffle reactor ( $\mathrm{ABR}$ ) dan wetland. Dalam penelitian ini digunakan sistem kombinasi anaerobic baffle reactor ( $A B R$ ) dan sistem lahan basah (wetland) ke dalam satu unit teknologi pengolahan air limbah untuk mengurangi ancaman limbah cair domestik bagi lingkungan. Proses kombinasi pengolahan dilakukan untuk meningkatkan efisiensi pengolahan limbah cair domestik. Limbah cair yang dihasilkan oleh rumah makan Raje Laot dikumpulkan ke dalam satu bak penampungan di dalam laboratorium untuk kemudian diolah dengan variasi waktu tinggal 24 jam, 48 jam dan 72 jam. Dalam studi kasus penelitian ini, hasil pengolahan terbaik dengan metode kombinasi ABR dan wetland mampu menurunkan konsentrasi pencemaran dengan nilai efisiensi pengolahan $\mathrm{pH} 6,47$, BOD sebesar 57,1 \%, TSS 72,4 \%, COD 58,7 \% dan Minyak-Lemak dengan efisiensi 97,1 \%. Nilai efisiensi tersebut menunjukan bahwa persentase penurunan konsentrasi pencemar paling baik terjadi pada waktu tinggal pengolahan 48 jam atau 2 hari.
\end{abstract}

Kata Kunci: Air Limbah domestik, ABR dan Wetland, Waktu tinggal, Efisiensi

\begin{abstract}
One of the problems that arise due to increased activity diner / restaurant is the contamination of water at sources of water pollution due to receive a load beyond its carrying capacity. Based on population density and population growth rate in Indonesia, the waste water that comes from eating home for the future potential to become a serious threat to the pollution of the water environment. This study aims to: (1) Knowing the characteristics of domestic wastewater restaurant Raje laot; (2) Determine the effectiveness of domestic wastewater treatment using a combination of anaerobic baffle reactor prosese (ABR) and wetland treatment technologies in one unit; (3) Knowing the best time staying domestic for treating wastewater by the combination process of anaerobic baffle reactor (ABR) and wetland. This study used a combination of anaerobic baffle reactor system (ABR) and the wetland system (wetland) into a single unit of wastewater treatment technologies to reduce the threat of domestic wastewater to the environment. The process of combination treatment is done to improve the efficiency of domestic wastewater treatment. Liquid waste generated by restaurants Raje laot gathered into the reservoirs in the laboratory and then processed with a variation of residence time $24 \mathrm{~h}, 48 \mathrm{~h}$ and $72 \mathrm{~h}$. In a case study of this research, the best processing results with the combination of $A B R$ and wetland method capable of lowering the concentration of pollution by processing efficiency value of $6.47 \mathrm{pH}$, BOD of $57.1 \%, 72.4 \%$ TSS, COD and $58.7 \%$ Oil-Fat with an efficiency of $97.1 \%$. The efficiency value indicates that the percentage reduction in the pollutant concentration occurs at a residence time of processing 48 hours or 2 days.
\end{abstract}

Keywords: Domestic Wastewater, ABR and Wetland, residence time, efficiency 


\section{Latar Belakang}

Berdasarkan tingkat kepadatan penduduk dan laju pertumbuhan penduduk di Indonesia, maka air limbah domestik di lingkungan pemukiman untuk masa yang akan datang potensial menjadi ancaman yang cukup serius terhadap pencemaran lingkungan perairan. Pertumbuhan penduduk di Indonesia yang pesat khususnya di kota-kota besar, telah mendorong peningkatan kebutuhan akan perumahan. Hal tersebut mengakibatkan timbulnya permasalahan pada sistem sanitasi lingkungan.

Dalam penelitian ini digunakan sistem kombinasi anaerobic baffle reaktor dan sistem lahan basah (wetland) ke dalam satu unit teknologi pengolahan air limbah untuk mengurangi ancaman limbah cair domestik bagi lingkungan. Proses kombinasi pengolahan dilakukan untuk meningkatkan efisiensi pengolahan limbah cair domestik. Oleh karena itu digunakan media lahan basah sebagai pengolahan lanjutan dari sistem ABR. Penelitian ini memanfaatkan tanaman hias Cyperus Papirus sebagai media tumbuh pada lahan basah. Model perancangan ini didasarkan pada banyaknya prilaku pedagang di kota Pontianak yang tidak melakukan pengelolaan terhadap limbah cair dagangannya.

\section{TInjauan Pustaka}

A. Limbah Cair

Limbah cair didefinisikan sebagai buangan cair yang berasal dari suatu lingkungan masyarakat dan lingkungan industri dimana komponen utamanya adalah air yang telah digunakan dan mengandung benda padat yang terdiri dari zat-zat organik dan anorganik.

Diantara beberapa jenis polutan, kandungan bahan organik dalam suatu limbah yang masuk ke badan air bebas perlu mendapat perhatian sebab dapat mengancam kehidupan biologis pada badan air tersebut. Kandungan bahan organik yang sangat tinggi memungkinkan terjadinya proses oksidasi bahan organik oleh mikroorganisme dalam badan air. Proses tersebut akan menggunakan oksigen terlarut dalam air, sehingga pada akhirnya ketersediaan oksigen bagi kehidupan di lingkungan tersebut berkurang. Hal ini dapat membawa bahaya kematian makhluk hidup di dalamnya (Tchobanoglous et al, 2003).

\section{B. Anaerobic baffle reaktor (ABR)}

Anaerobic Baffled Reaktor (ABR) merupakan sistem pengolahan tersuspensi anaerob, dalam biorektor berpenyekat. Pertumbuhan tersuspensi (suspended growth) lebih menguntungkan dibanding pertumbuhan melekat (attached growth) karena tidak membutuhkan media pendukung serta tidak mudah tersumbat. Anaerobic Baffled Reaktor (ABR) dikembangkan oleh McCarty dan rekan-rekannya di Universitas Stanford (Mc Carty 1981 dalam Wang, 2004).

Kelebihan-kelebihan utama ABR adalah :

1. ABR mampu memisahkan proses asidogenesis dan metanogenesis secara longitudinal yang memungkinkan reaktor memiliki sistem dua fase (two stage), tanpa adanya masalah pengendalian dan biaya tinggi (Barber et al 1999, dalam Movahedyan, 2007).

2. Desainnya sederhana, tidak memerlukan pengaduk mekanis, biaya konstruksi relatif murah, biomassa tidak memerlukan karakteristik pengendapan tertentu, lumpur yang dihasilkan rendah, SRT tinggi dicapai tanpa media pendukung serta tidak memerlukan sistem pemisahan gas (Bell, 2002). Peningkatan volume limbah cair tidak masalah, bahkan memungkinkan operasional intermitten, selain itu ABR stabil terhadap adanya beban kejut hidrolik dan organik 
(hyhraulic and organik shock loading) selain itu konfigurasi ABR melindungi biomassa dari senyawa toksik dalam influen (Barber et al 1999, dalam Bell, 2002).

3. Selain itu pola hidrodinamik ABR dapat mereduksi terbuangnya bakteri (bacterial washout) dan mampu menjaga biomassa tanpa penggunaan fixed media (Grover et al 1999, dalam Movahedyan, 2007). Pemisahan dua fase menyebabkan peningkatan perlindungan terhadap senyawa toksik dan memiliki ketahanan terhadap perubahan parameter lingkungan seperti $\mathrm{pH}$, temperatur dan beban organik (Barber et al 1999, dalam Movahedyan, 2007).

\section{Sistem Lahan Basah (Wetland)}

Sistem Lahan Basah Buatan (Constructed Wetland) merupakan proses pengolahan limbah yang meniru/aplikasi dari proses penjernihan air yang terjadi dilahan basah/rawa (Wetland), dimana tumbuhan air (Hydrophita) yang tumbuh didaerah tersebut memegang peranan penting dalam proses pemulihan kualitas air limbah secara alamiah (self purification).

Sistem Aliran Bawah Permukaan (Sub Surface Flow-Wetland) merupakan sistem pengolahan limbah yang relatif masih baru, namun telah banyak diteliti dan dikembangkan oleh banyak negara dengan berbagai alasan. Menurut Tangahu et al (2001), bahwa pengolahan air limbah dengan sistem tersebut lebih dianjurkan karena beberapa alasan sebagai berikut :

- Dapat mengolah limbah domestik, pertanian dan sebagian limbah industri termasuk logam berat.

- Efisiensi pengolahan tinggi (80\%).

- Biaya perencanaan, pengoperasian dan pemeliharaan murah dan tidak membutuhkan ketrampilan yang tinggi.

Constructed wetland ada dalam berbagai bentuk dan ukuran, tergantung dari pemilihan dan evaluasi lokasi. Sistem ini bisa disesuaikan ke hampir semua lokasi dan bisa dibangun dalam banyak konfigurasi dari unit tunggal kecil yang hanya beberapa meter persegi sampai sistem dengan luas beratus hektar.

\section{Metode Penelitian}

\section{A. Waktu dan Lokasi Penelitian}

Penelitian dilaksanakan selama 4 bulan yang dimulai dari bulan Maret 2014 dan berakhir hingga Juni 2014. Penelitian dilakukan di Laboratorium Teknik Lingkungan Universitas Tanjungpura Pontianak.

\section{B. Alat dan Bahan}

Dalam melakukan proses penelitian ini diperlukan beberapa alat yang menunjang pembuatan dan kinerja reaktor dalam mengolah limbah cair domestik dari rumah makan. Diantara alat-alat tersebut adalah Drum 200 liter untuk membuat reaktor, jerigen 20 liter 5 buah untuk mengambil sampel, pipa $3 / 4$ inch 1 buah, stop kran $3 / 46$ buah, soket tanki 5 buah, serta gelas ukur $1000 \mathrm{ml}$.

Bahan-bahan yang digunakan dalam penelitian ini merupakan bahan-bahan utama yang mendukung terjadinya proses pengolahan yang baik. Adapun bahan-bahan yang digunakan dalam penelitian ini adalah Bakteri EM4 pengolahan limbah 3 botol untuk melakukan seeding bakteri, limbah cair rumah makan sebagai bahan utama pengolahan, tanaman Cyperus Papirus yang merupakan tanaman hias yang dapat memperindah dan mengolah air limbah. Adapun rancangan reaktor penelitian dapat dilihat pada gambar 1 . 


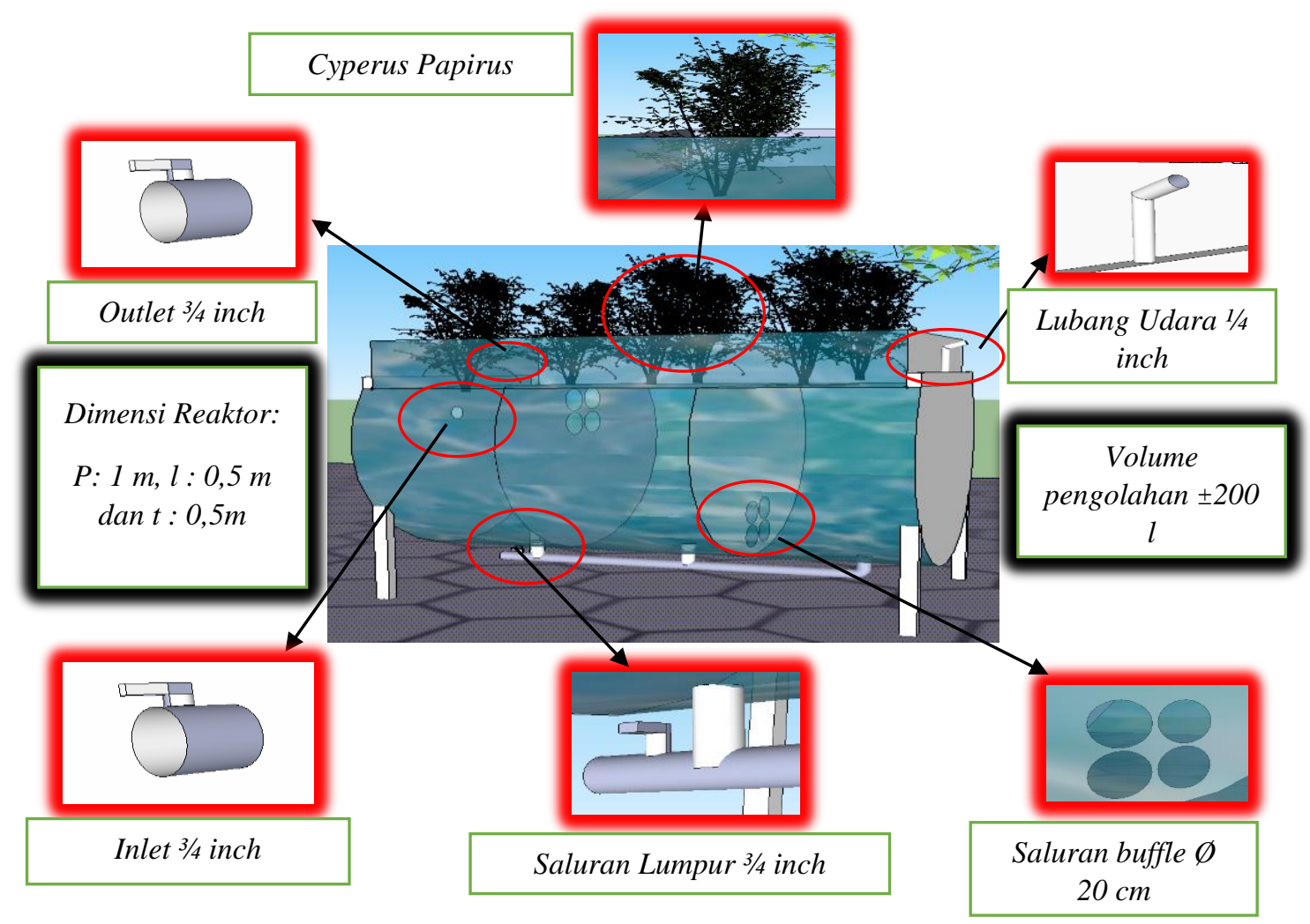

Gambar 1. Rancangan reaktor penelitian sistem kombinasi ABR dan Wetland

\section{Hasil dan Pembahasan}

A. Karakteristik Limbah Cair RM. Raje Laot

Limbah yang digunakan dalam penelitian ini adalah limbah cair rumah makan yang berlokasi di jalan Imam Bonjol, Pontianak. Konsentrasi zat yang terkandung dalam limbah tersebut berfluktuasi sesuai dengan jumlah produksi dan jumlah air bersih yang digunakan. Adapun karakteristik limbah tersebut dapat dilihat pada table 1.

Tabel 1. Karakteristik Limbah Cair RM. Raje Laot yang Digunakan Dalam Penelitian

\begin{tabular}{clcrc} 
NO & Parameter & Satuan & Konsentrasi & Konsentrasi* \\
\hline 1 & $\mathrm{pH}$ & - & 5.31 & $6-10$ \\
2 & $\mathrm{TSS}$ & $\mathrm{mg} / \mathrm{L}$ & 312 & 100 \\
3 & $\mathrm{BOD}$ & $\mathrm{mg} / \mathrm{L}$ & 118.64 & 100 \\
4 & Minyak lemak & $\mathrm{mg} / \mathrm{L}$ & 315 & 10 \\
5 & COD & $\mathrm{mg} / \mathrm{L}$ & 603.81 & 200 \\
\hline
\end{tabular}

*Konsentrasi berdasarkan Baku Mutu PERMEN LH 1122003 


\section{B. Penyisihan Polutan Pada Air Limbah RM. Raje Laot Dengan Sistem Kombinasi Pengolahan ABR dan Constructed Wetland.}

Parameter yang dianalisa pada percobaan ini terdiri dari parameter utama air buangan untuk air limbah domestik yaitu pH, BOD, TSS, minyak dan lemak yang telah ditetapkan dalam PERMEN LH No.112 Tahun 2003. Untuk parameter COD dilakukan analisa untuk mengetahui nilai organik removal dari hasil pengolahan air limbah. Hasil pengolahan dalam penelitian ini dapat dilihat pada table 2 .

Tabel 2. Hasil Penelitian Pada Semua Parameter

\begin{tabular}{|c|l|c|c|c|c|c|c|c|}
\hline \multirow{2}{*}{ No } & \multirow{2}{*}{ Parameter } & \multirow{2}{*}{$\begin{array}{c}\text { Konsentrasi } \\
\text { Limbah }\end{array}$} & \multicolumn{3}{|c|}{ Waktu Tinggal } & \multicolumn{3}{|c|}{ Efisiensi (\%) } \\
\cline { 4 - 9 } & & & $\mathbf{1}$ hari & 2 Hari & 3 Hari & 1 hari & 2 Hari & 3 Hari \\
\hline $\mathbf{1}$ & $\mathbf{p H}$ & 5.31 & 6.385 & 6.425 & 6.5 & - & - & - \\
\hline $\mathbf{2}$ & TSS & 312 & 110 & 86 & 124 & 64.7 & 72.4 & 60.3 \\
\hline $\mathbf{3}$ & BOD & 118.64 & 76.26 & 50.84 & $\begin{array}{c}127.1 \\
1\end{array}$ & 35,7 & 57.1 & - \\
\hline $\mathbf{4}$ & Minyak lemak & 315 & 63 & 18 & 9 & 80.0 & 94.3 & 97.1 \\
\hline $\mathbf{5}$ & COD & 603.81 & 447.6 & 249.5 & $\begin{array}{c}379.0 \\
4\end{array}$ & 25.9 & 58.7 & 37.2 \\
\hline
\end{tabular}

\section{B.1 pH}

Pengukuran $\mathrm{pH}$ merupakan hal yang mutlak dilakukan di dalam pengolahan air limbah. $\mathrm{pH}$ menunjukkan konsentrasi ion hidrogen di dalam larutan. Semakin tinggi nilai pH artinya konsentrasi ion hidrogen semakin sedikit dan larutan akan bersifat basa. Sebaliknya, semakin rendah nilai pH maka larutan akan memiliki sifat asam karena konsentrasi ion hidrogen semakin tinggi.

Dalam pengolahan limbah yang melibatkan proses biologi, peranan $\mathrm{pH}$ sangat penting. Mikroorganisme memerlukan lingkungan dengan $\mathrm{pH}$ tertentu. Secara umum, rentang $\mathrm{pH}$ yang dapat ditolerir oleh mikroorganisme adalah pada kisaran 6.5 - 8.5. $\mathrm{pH}$ yang tidak sesuai atau terlalu fluktuatif dapat menurunkan kinerja proses biologi karena mikroorganisme tidak dapat melakukan metabolisme secara optimal. Hasilnya, proses penyisihan organik dari dalam air limbah (diwakili oleh BOD) tidak dapat berjalan dengan semestinya dan efisiensi pengolahan dapat menurun. (Khiatudin, 2003)

Nilai $\mathrm{pH}$ berkaitan erat dengan konsentrasi $\mathrm{CO}_{2}$ dalam limbah cair. Dengan demikian, peningkatan nilai $\mathrm{pH}$ yang diolah dengan proses anaerob disebabkan adanya aktivitas mikroorganisme (bakteri) dalam pemanfaatan $\mathrm{CO}_{2}$. Pemanfaatan $\mathrm{CO}_{2}$ oleh bakteri akan meyebabkan terjadinya peningkatan nilai $\mathrm{pH}$. Hal ini disebabkan bertambahnya bahan-bahan organik yang membebaskan $\mathrm{CO}_{2}$ dari proses penguraian bahan organik yang dilakukan oleh bakteri. Gas $\mathrm{CO}_{2}$ yang dihasilkan oleh mikroorganisme dari penguraian zat organik akan berdifusi dengan air dan akan terbentuk asam karbonat yang bersifat asam dari reaksi $\mathrm{CO}_{2}+\mathrm{H}_{2} \mathrm{O} \leftrightarrow \mathrm{H}_{2} \mathrm{CO}_{3}$ (Sunu,P., 2001). Dengan nilai pH yang cenderung asam ini, maka diperlukan pengolahan agar nilai tersebut mencapai $\mathrm{pH}$ netral sesuai dengan baku mutu air limbah yang berlaku. Pengolahan yang dilakukan 
menunjukan bahwa $\mathrm{pH}$ hasil pengolahan meningkat ke arah nilai baku mutu $\mathrm{pH}$ yang disyaratkan yang dapat dilihat pada gambar 2.

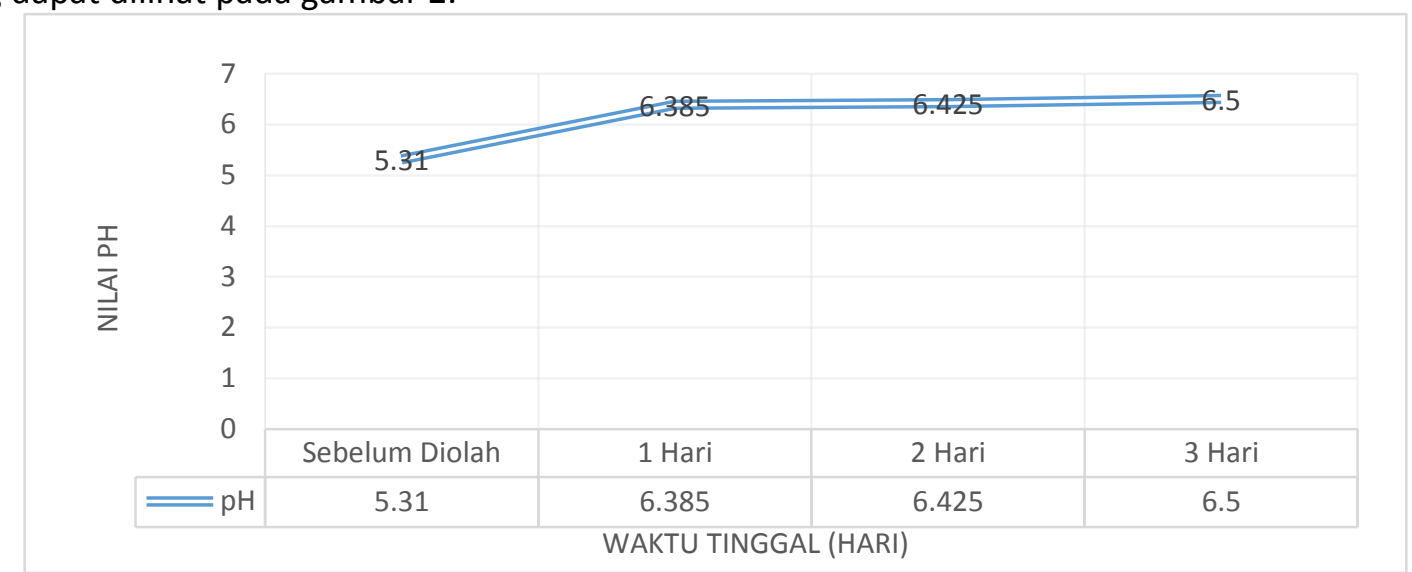

Gambar 2. Hasil analisa pH pada setiap waktu tinggal

\section{B.2 Penyisihan BOD}

Angka BOD adalah jumlah oksigen yang dibutuhkan oleh bakteri untuk menguraikan hampir semua zat organik yang terlarut dan sebagian zat organik yang tersuspensi dalam air limbah. Dalam hal ini diinterpretasikan bahwa senyawa organik merupakan makanan bagi bakteri dan energi merupakan hasil dari proses penguraian tersebut. Makin tinggi angka BOD, maka air semakin tercemar.

Konsentrasi BOD influen untuk ketiga reaktor A, B, dan C adalah 118,64 mg/l, sedangkan efluen rata-rata dari semua rekator $A, B$, dan $C$ adalah 76,265 mg/l, 50,84 mg/l dan 127,115 mg/l. Efluen pada penyisihan BOD pada reaktor $A$ dan $B$ menunjukan efisiensi pengolahan yang cukup baik dengan nilai efisiensi $35,7 \%$ dan $57,1 \%$. Adapun reaktor $C$ menunjukan nilai efisiensi negatif () tidak menunjukan efisiensi pengolahan yang baik karena pada reaktor ini terjadi peningkatan konsentrasi BOD hingga melampaui konsentrasi BOD sebelum diolah dan nilai baku mutu yang telah ditetapkan.

Terjadinya peningkatan konsentrasi BOD pada reaktor $\mathrm{C}$ dengan waktu tinggal pengolahan 3 hari dapat disebabkan karena proses penguraian bahan organik oleh bakteri yang tidak lagi bisa bekerja sebagaimana mestinya. Kondisi ini dapat disebabkan karena kematian bakteri yang dapat terjadi karena kurangnya ketersediaan nutrient limbah bagi tumbuh kembang bakteri. Dalam kasus ini nutrient/air limbah terus dialirkan ke dalam reaktor pengolahan sementara bakteri dalam reaktor tersebut sudah mati, kondisi ini menyebakan meningkatnya kandungan organik (BOD) pada reaktor pengolahan $\mathrm{C}$ karena ketidak seimbangan antara jumlah bakteri dan nutrient/limbah yang dimasukkan dalam reaktor tersebut. Hal tersebut sejalan dengan apa yang disampaikan oleh Brock \& Madigan (1991) yang menyatakan bahwa akumulasi produk limbah, kekurangan nutrient, perubahan $\mathrm{pH}$, dan factor lain yang tidak diketahui akan mendesak dan mengganggu biakan, mengakibatkan penurunan kecepatan pertumbuhan. Selama fase ini, jumlah sel yang hidup tetap konstan untuk periode yang berbeda, bergantung pada bakteri, tetapi akhirnya menuju periode penurunan populasi. Pada saat medium kehabisan nutrient maka populasi bakteri akan menurun jumlahnya. Pada saat ini jumlah sel yang mati lebih banyak daripada sel yang hidup. Perbandingan hasil pengolahan air limbah pada setiap waktu tinggal dapat dilihat pada gambar 3. 


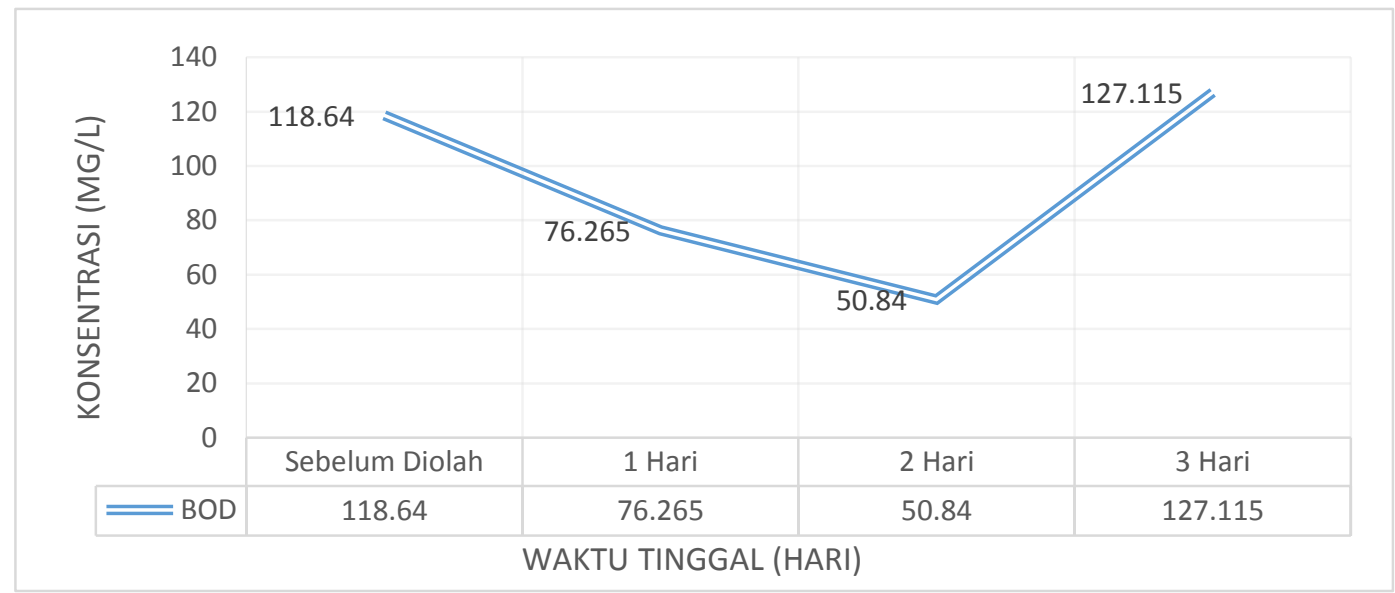

Gambar 3. Hasil Analisa BOD pada setiap waktu tinggal

\section{B.3 Penyisihan TSS}

Total suspended solid (TSS) atau total padatan tersuspensi adalah padatan yang tersuspensi di dalam air berupa bahan organik dan anorganik yang dapat disaring dengan kertas millipore berpori 0,45 $\mu \mathrm{m}$. Materi yang tersuspensi mempunyai dampak buruk terhadap kualitas air karena mengurangi penetrasi matahari ke dalam badan air dan meningkatkan kekeruhan dalam air.

Konsentrasi total influen padatan tersuspensi untuk semua reaktor A, B, dan C adalah 312 $\mathrm{mg} / \mathrm{l}$. Nilai tersebut telah melampaui baku mutu yang telah ditetapkan untuk TSS yaitu $100 \mathrm{mg} / \mathrm{l}$. Oleh karena itu air limbah harus diolah terlebih dahulu agar tidak memiliki dampak buruk bagi lingkungan.

Pengolahan air limbah yang dilakukan dengan metode kombinasi ABR dan constructed wetland menghasilkan efluen dengan konsentrasi TSS yang berbeda-beda disetiap reaktornya. Reaktor A yang diolah dengan waktu tinggal 1 hari memiliki nilai konsentrasi $110 \mathrm{mg} / \mathrm{l}, 86 \mathrm{mg} / \mathrm{l}$ untuk reaktor B, dan $124 \mathrm{mg} / \mathrm{I}$ untuk reaktor C. Hasil pengolahan menunjukan terjadinya penurunan konsentrasi TSS jika dibandingkan dengan konsentrasi awal sebelum dilakukan pengolahan dengan nilai efisiensi pengolahan pada reaktor A 64,7\%, 72 \% pada reaktor B, dan $60 \%$ pada reaktor C. Dengan demikian hasil pengolahan menunjukan bahwa efisiensi terbaik terdapat pada reaktor $B$ dengan waktu detensi 2 hari. Efisiensi penyisihan tersebut dapat dilihat pada gambar 4.3 hasil analisa TSS pada semua reaktor pengolahan.

Pola penyisihan konsentrasi TSS pada setiap reaktor menunjukan bahwa terjadi peningkatan konsentrasi TSS pada reaktor $C$ dengan waktu tinggal 3 hari Penurunan konsentrasi TSS yang terukur dalam effluent tiap HRT seiring dengan penurunan konsentrasi COD. Hal ini sesuai dengan pernyataan Metcalf \& Edy (1993) bahwa dengan penurunan nilai TSS, maka konsentrasi COD juga akan mengalami pengurangan. 


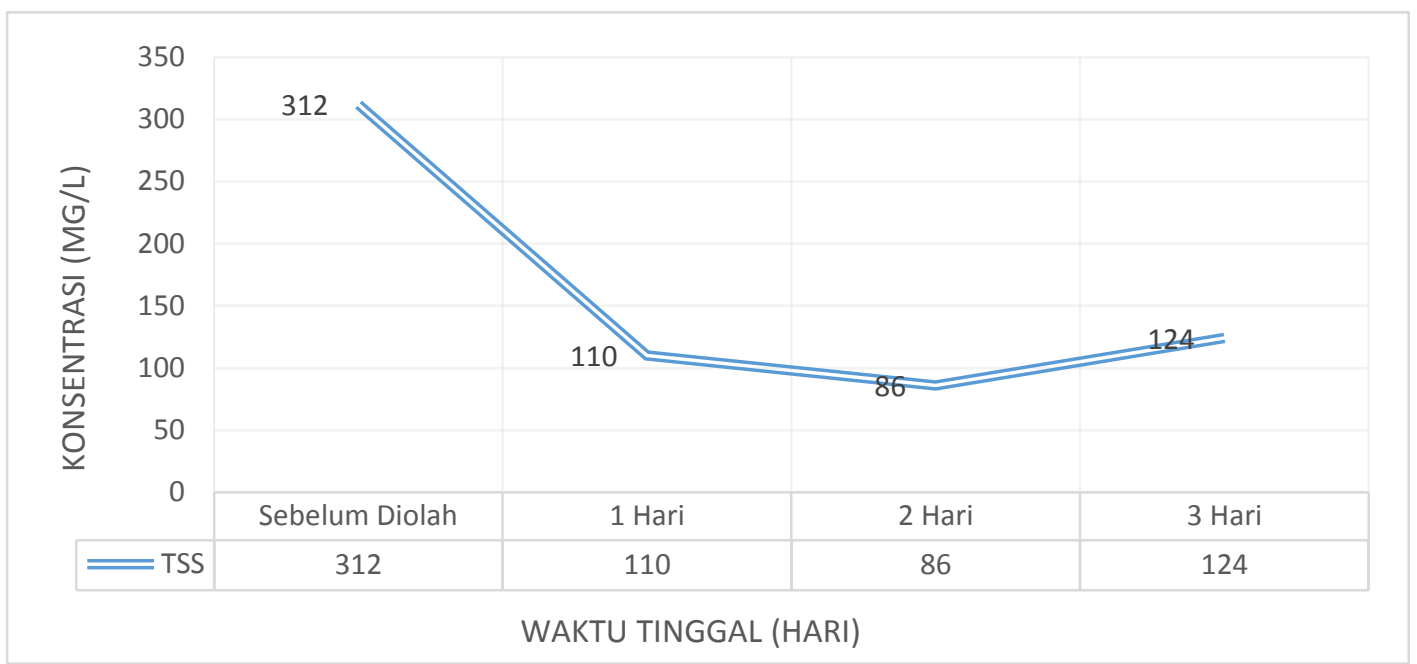

Gambar 4. Hasil analisa TSS pada setiap waktu tinggal

\section{B.4 Penyisihan Minyak dan Lemak}

Konsentrasi kandungan minyak-lemak dalam limbah cair RM. Raje laot sebelum melalui reaktor pengolahan air limbah adalah sebesar $315 \mathrm{mg} / \mathrm{l}$ dan setelah melewati pengolahan dengan sistem kombinasi ABR dan constructed wetland adalah $63 \mathrm{mg} / \mathrm{l}$ pada reaktor A dengan waktu tinggal 1 hari, $18 \mathrm{mg} / \mathrm{l}$ pada reaktor B untuk waktu tinggal 2 hari, dan $9 \mathrm{mg} / \mathrm{l}$ pada reaktor $C$ untuk waktu tinggal 3 hari. Adapun grafik hasil analisa penyisihan minyak dan lemak dapat dilihat pada gambar 5.

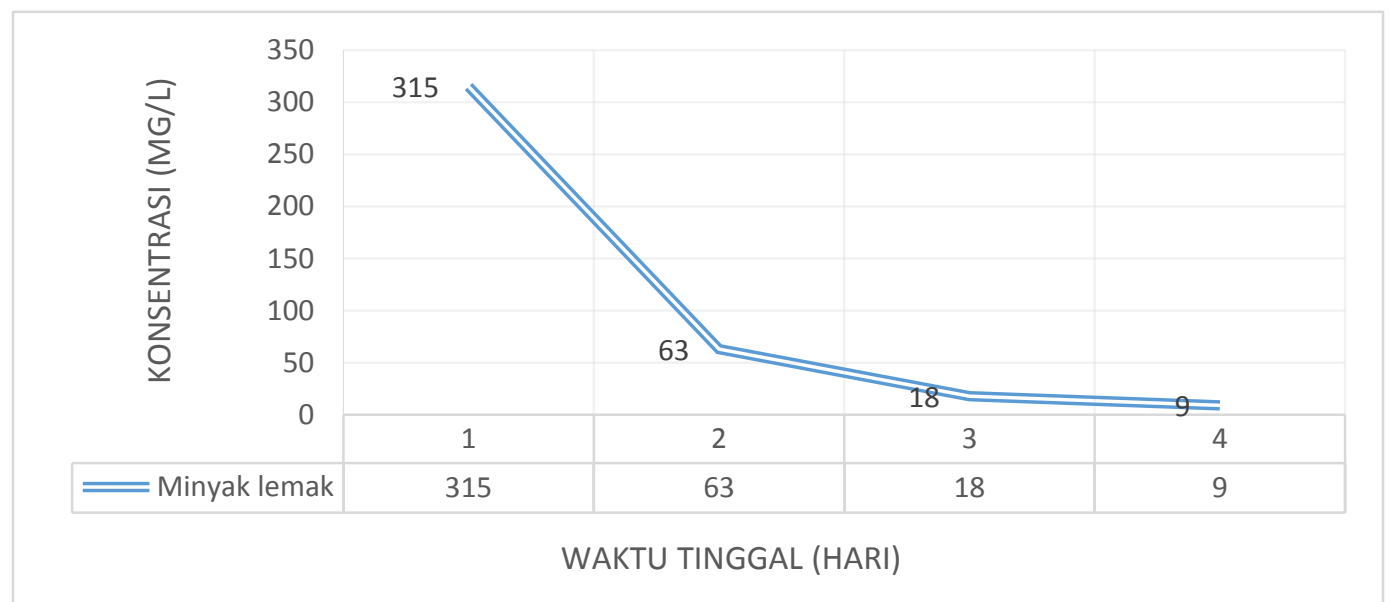

Gambar 5. Hasil analisa minyak dan lemak pada setiap waktu tinggal

Berdasarkan hasil tersebut maka efisiensi penyisihan minyak-lemak pada reaktor A adalah $80,0 \%$, pada reaktor B 94,3 \% dan pada reaktor C 97,1 \%. Walaupun telah terjadi penurunan kandungan minyak-lemak sebesar $80,0 \%$ pada reaktor $A$, tetapi nilainya tetap saja melebihi baku mutu yang disyaratkan berdasarkan Kepmen LH No.112 tahun 2003 yaitu 10 mg/l. Penyisihan konsentrasi minyak-lemak semakin menurun pada reaktor B dengan waktu tinggal 2 hari, meskipun demikian konsentrasi minyak-lemak masih belum memenuhi baku mutu yang disyaratkan. 
Penyisihan tertinggi ditunjukan pada reaktor $\mathrm{C}$ dengan waktu tinggal 3 hari, penyisihan pada tahap ini mampu menurunkan konsentrasi awal minyak-lemak mencapai baku mutu yang disyaratkan.

\section{B.5 Penyisihan COD}

Pengujian parameter COD pada penelitian ini dilakukan untuk mengetahui nilai Organik Loading Rate (OLR) dari setiap waktu tinggal pengolahan. Konsentrasi COD pada air limbah RM. Raje Laot sebelum diolah adalah $603,81 \mathrm{mg} / \mathrm{l}$. Setelah dilakukan pengolahan dengan variasi waktu tinggal 1 hari, 2 hari dan 3 hari maka hasil pengolahan menunjukan bahwa nilai konsentrasi COD hasil pengolahan adalah 447,6 mg/l, 249,5 mg/l dan 379,04 mg/l. Dengan demikian penyisihan terbaik terdapat pada hari ke-dua dengan nilai konsentrasi COD 249,5 mg/l. Berdasarkan hal tersebut maka dapat dihitung nilai Organik Loading Rate (OLR) dari setiap waktu pengolahan. Nilai OLR pada setiap waktu tinggal adalah 18,65 mg/jam pada waktu tinggal 1 hari, 5,19 mg/jam dengan waktu tinggal 2 hari, dan 5,26 mg/jam dengan waktu tinggal pengolahan 3 hari.

Dari hasil penelitian menunjukan bahwa kecenderungan penurunan konsentrasi COD yang sejalan dengan penurunan konsentrasi BOD mengindikasikan bahwa bahan organik yang terkandung dalam air limbah sebagian besar merupakan bahan organik yang bersifat biodegradable. Hal senada juga dinyatakan oleh Tebbut dalam Effendi, H (2003), bahwa komposisi padatan yang terdapat dalam limbah domestik, $70 \%$ merupakan bahan organik.

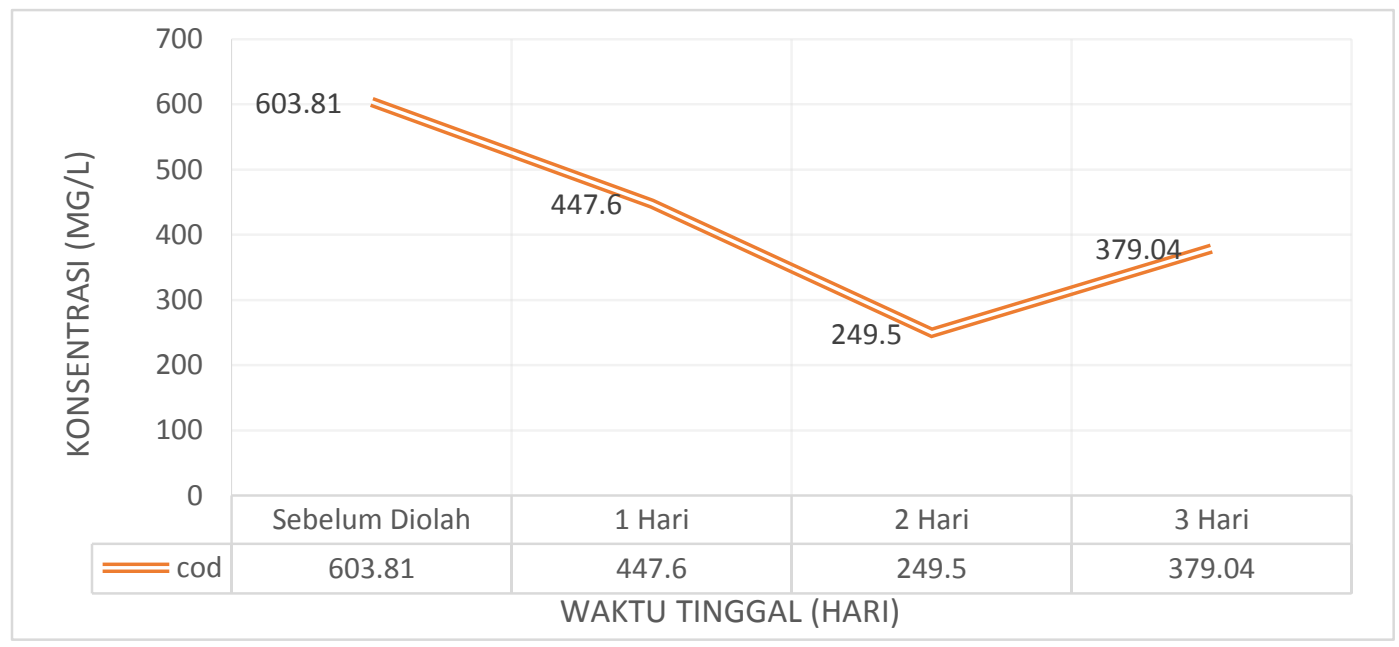

Gambar 6. Hasil analisa COD pada setiap waktu tinggal

\section{Kesimpulan dan Saran}

A. Kesimpulan

Dari penelitian yang dilakukan mengenai pengolahan air limbah domestik dengan sistem kombinasi Anaerobik Baffle Reaktor (ABR) dan Constructed Wetland dapat diambil beberapa kesimpulan, yaitu :

1. Berdasarkan hasil penelitian, maka dapat diketahui bahwa efluen limbah yang dikeluarkan oleh RM. Raje Laot mengandung konsentrasi pH 5.31, BOD 118.64, COD 603.81, TSS 312, minyak lemak 315 yang masih melampaui baku mutu yang disyaratkan oleh pemerintah dalam PERMEN LH 112 Tahun 2003.

2. Efluen hasil pengolahan telah turun hingga memenuhi baku mutu yang disyaratkan kecuali COD yang masih diatas baku mutu. Efisiensi terbaik pada pengolahan ditunjukkan pada hari kedua 
dengan nilai efisiensi penurunan TSS $72,4 \%$, BOD $57,1 \%$, COD $58,7 \%$, minyak dan lemak $94,3 \%$ dan $\mathrm{pH}$ dengan nilai 6,47 .

3. Waktu tinggal terbaik dalam penelitian ini ditunjukan pada hari kedua dengan waktu tinggal 48 jam.

\section{B. Saran}

Penelitian ini masih perlu dikembangkan untuk memaksimalkan proses pengolahan dengan sistem kombinasi ABR dan Constructed Wetland. Proses seeding dan pemberian nutrient perlu diperhatikan agar proses degradasi limbah oleh mikroorganisme dapat berjalan dengan maksimal. Penambahan grease trap perlu ditambahkan dalam model pengolahan ini untuk optimalisasi pengolahan yang lebih baik.

\section{Ucapan Terimakasih}

Ucapan Terimakasih sebesar-besarnya penulis sampaikan kepada seluruh dosen pengajar Program Studi Teknik Lingkungan Fakultas Teknik UNTAN, terutama kepada dosen pembimbing penulis Ibu Isna Apriani, ST.Msi dan Ibu Ir.Rita Hayati,Sp.Msi serta dosen penguji Ibu Yulisa Fitrianingsih,ST.MT dan Ibu Dian Rahayu Jati, ST.MT atas bimbingan, arahan, kritik dan saran yang telah diberikan sehingga proses penelitian hingga penulisan jurnal ini dapat penulis selesaikan dengan baik. Semoga hasil penelitian dan jurnal ini dapat memberikan manfaat bagi masyarakat dan ilmu pengetahuan. Terimakasih

\section{Referensi}

Bell J. 2002. Treatment of Dye Wastewaters in The Anaerobic Baffled Reaktor and Characterisation of The Associated Microbial Populations. Ph.D. Thesis, School of Chem. Eng., Univ. of Natal, Durban.

Brock, T.D. \& Madigan, M.T.1991. Biology of Microorganisms. $6^{\text {th }}$ Ed. Prentice-Hall International,Inc. New Jersey

Effendi, H. 2003. Telaah Kualitas Air : Bagi Pengelolaan Sumber Daya dan Lingkungan Perairan, Penerbit Kanisius, Yogyakarta.

Khiatuddin. 2003. Melestarikan Sumber Daya Air Dengan Teknologi Rawa Buatan. Gadjah Mada University Press. Yogyakarta.

Metcalf \& Eddy. 1993. Wastewater Engineering : Treatment and Reuse. Fourth Edition.International Edition. McGraw-Hill, New York.

Movahedyan, H., A. Assadi and A. Parvaresh.2007. Performance Evaluation of ABR Treating Wheat Flour Starch Industry Wastewater. Iran J. Environ. Health Sci. Eng. 4 (2): 77-84.

Sunu, Pramudya. 2001. Melindungi Lingkungan Dengan Menerapkan ISO 14001. PT. Gramedia Widiasarana Indonesia. Jakarta.

Tangahu, B.V. dan Warmadewanthi, I.D.A.A. 2001. Pengelolaan Limbah Rumah Tangga Dengan Memanfaatkan Tanaman Cattail (Typha angustifolia) dalam Sistem Constructed Wetland, Purifikasi. Volume 2 Nomor 3. ITS - Surabaya.

Tchobanoglous, George, L. Burton, Franlin, Stense, H. David. 2003. Wastewater Engginering Treatment Disposal Reuse, Fourth Eition. McGrow Hill Book Co, Amerika.

Wang JL, Huang YH, Zhao X. 2004. Performance and Characteristics of an Anaerobic Baffled Reaktor. Bioresour. Technol 